Canadian Journal of Higher Education Revue canadienne d'enseignement supérieur

Volume 45, No. 4, 2015, pages 63 - 80

\title{
Measuring Systemic and Climate Diversity in Ontario's University Sector
}

Pierre Gilles Piché

University of Toronto

\begin{abstract}
This article proposes a methodology for measuring institutional diversity and applies it to Ontario's university sector. This study first used hierarchical cluster analysis, which suggested there has been very little change in diversity between 1994 and 2010 as universities were clustered in three groups for both years. However, by adapting Birnbaum's (1983) diversity matrix methodology to Ontario's university sector, the author appears to have found a decrease in systemic diversity (differences in the type of institution and size of institution; Birnbaum, 1983) and climate diversity (differences in campus environment and culture; Birnbaum, 1983) between 1994 and 2010. Policy implications resulting from this study are also considered.
\end{abstract}

\section{Résumé}

Cet article propose une méthodologie pour mesurer la diversité institutionnelle, et l'applique au secteur universitaire de l'Ontario. De prime abord, l'étude a utilisé une analyse de classification hiérarchique suggérant un faible taux de changement de diversité entre 1994 et 2010, période durant laquelle les universités se divisaient en trois groupes. Toutefois, en adaptant la méthodologie de mesure de la diversité de Birnbaum (1983) aux universités de l'Ontario, l'auteur semble avoir décelé une diminution de la diversité systémique (différence dans le type et la grandeur de l'institution, Birnbaum, 1983) et de la diversité climatique (différence dans l'environnement et la culture d'un campus, Birnbaum, 1983) entre 1994 et 2010. L'auteur a également pris en compte les effets de cette étude sur les politiques. 


\section{Introduction}

The extent and nature of institutional differentiation are one design choice among many that must be considered by policy makers when developing a higher education system or when dealing with an increased number of students and growing societal demands for undergraduate and graduate education. While the worldwide process of institutional differentiation in higher education is not a new phenomenon, it has received increased attention recently in Ontario as the current environment of fiscal restraint (and calls for greater efficiency) due to the 2008 global economic crisis restricts the province's ability to increase funding to its university sector; meanwhile, public pressure to increase access continues unabated. Quality advances that have been made in the past 10 years as a result of the provincial government's significant investment in higher education also need to be maintained. Ontario has recently moved to reconsider the design of its higher education system by adopting a differentiation policy framework as "the foundation for the ministry's decision making and ongoing dialogue with institutions, students, and all stakeholders going forward" (Ontario Ministry of Training, Colleges and Universities, 2013, p. 9). This framework is in need of a model to quantify the level of diversity, to form the basis for policy development and move the sector forward in these difficult economic times. This article proposes a methodology for measuring institutional diversity and applies it to Ontario's university sector.

Only a few studies worldwide have measured the level of diversity and differentiation in higher education systems (Birnbaum, 1983; Huisman, 2000; Huisman, Meek, \& Wood, 2007; Morphew, 2009; Stanley \& Reynolds, 1994; Zha, 2009). While some studies have used programmatic diversity-differences in degree level, mission, and program emphasis (Birnbaum, 1983) - as a proxy for institutional diversity (Lepori, Huisman, \& Seeber, 2014; Rossi, 2010; Teixeira, Rocha, Biscaia, \& Cardoso, 2012), no studies have attempted to quantify the level of systemic and climate diversity in Ontario's university sector or any other province in Canada. In this study, diversity refers to the number of types of universities within Ontario's university sector, derived from classifying universities according to one or more characteristics, and to the dispersion of universities across types at a point in time (as informed by Huisman, 1998).

This article will focus on institutional diversity and more specifically on systemic diversity, because governments around the world are concerned about increasing or maintaining diversity in their higher education systems as a means of increasing access or managing the increased demand for higher education. Systemic diversity is important because it provides a variety of choices to diverse groups of learners that can ensure a better match between the needs of students and the types of institutions. Some students may seek the personal attention offered at a small campus, while others may seek more cosmopolitan campuses. Systemic diversity also ensures that the purposes and functions of institutions are more efficiently discharged. Systemic diversity in this study refers to the number of types of universities within Ontario's university sector, derived from classifying universities according to their institutional type and size, and to the dispersion of universities across types at a point in time (as informed by Huisman, 1998).

This article will also focus on climate diversity, because Ontario universities have recently become increasingly aware of the importance of increased student-faculty interac- 
tions to an outstanding student experience; at the same time, they are being provided with additional funding to expand graduate enrolment in the province. Climate diversity is also important because it provides a variety of environments that can better meet the needs of a diverse student body, thereby increasing student satisfaction and engagement. Student needs and abilities can also be met through the characteristics of the other students attending the same institution, by the various levels of interactions with faculty, or by the research or educational focus of institutions. Climate diversity refers to the number of types of universities within Ontario's university sector, derived from classifying universities according to their social environment and culture, and to the dispersion of universities across types at a point in time (as informed by Huisman, 1998).

\section{Overview of Ontario's Higher Education Sector}

In 2010, Ontario's public higher education system consisted of 21 provincially-assisted universities and their affiliates, 24 publicly assisted colleges of applied arts and technology, three agricultural colleges affiliated with a university, one applied health science institute, and one military college.

Ontario universities are autonomous not-for-profit corporations, each created by a separate provincial act that, in almost all instances, provides it with the authority to grant both undergraduate and graduate degrees. The province essentially has a monopoly on degree granting by its ability to provide the right to publicly supported universities to offer degrees through legislation. All universities provide graduate programs, with the exception of Algoma, the newest university in Ontario. There are differences in the program mixes offered by the various universities but their missions, as stated in their legislation, are very similar. Ontario universities operate, like those in many other countries, within a neo-liberal political framework characterized by an increased focus on the private benefits of higher education, the use of competition in funding allocation models, and increased accountability measures.

Colleges in Ontario were all established under a single statute and focus mainly on vocational education. In 2000, they were provided with the authority to offer applied baccalaureate programs in applied fields of study. "College degree granting represents $4 \%$ of college enrolment (2011), and 2\% of overall Ontario degree-level enrolment” (Hicks, Weingarten, Jonker, \& Liu, 2013, p. 3). Colleges also engage in applied research in varying degrees and seek to provide programs in response to their local communities. Starting in 2003, five colleges were differentiated from the others by being assigned the status of institute of technology and advanced learning, which allows them to offer up to $15 \%$ of their programs in applied degrees, as compared with $5 \%$ for those without this status. Colleges do not have statutory authority to grant degrees; they must obtain approval for each program from the Ontario Minister of Training, Colleges and Universities, who grants approval for a limited time.

Using the boundaries established for Ontario's demographic forecasts by the Ontario Ministry of Finance, Fallis (2013) observed that universities are well distributed geographically across the province. The distribution speaks to Ontario's commitment to providing post-secondary education to all qualified students who wish to attend without forcing them to leave their regions. Table 1 replicates the geographical distribution of universities by region, as followed by Fallis, and adds their associated institutional type. Stu- 
dents in each region have access to all four types of institutions, except in the Southwest region, which lacks a special-purpose institution, and the Northern region, which lacks a comprehensive institution and a medical/doctoral institution.

Table 1.

Ontario Universities by Region and Type, 2010

\begin{tabular}{lllll}
\hline Southwest & Central & Greater Toronto & East & Northern \\
\hline Brock (1) & Guelph (2) & OCAD (4) & Carleton (2) & Algoma (4) \\
Western (3) & Laurier (1) & Ryerson (1) & Trent (1) & Lakehead (1) \\
Windsor (2) & McMaster (3) & Toronto (3) & Ottawa (3) & Laurentian (1) \\
& Waterloo (2) & UOIT (1) & Queen's (3) & Nipissing (1) \\
& Redeemer (4) & York (2) & Dominican (4) \\
& & \multicolumn{3}{c}{ Royal Military (4) } \\
Note: (1) Primarily undergraduate, (2) Comprehensive, (3) Medical/doctoral, (4) Special-purpose.
\end{tabular}

\section{Theoretical Framework and Methodology}

The changes in institutional diversity in Ontario were examined using population ecology, derived from organizational theory, as the study's main theoretical framework. Population ecology theory focuses "on the sources of variability and homogeneity of organizational forms. It pays considerable attention to population dynamics, especially the processes of competition among diverse organizations for limited resources such as membership, capital and legitimacy" (Hannan \& Freeman, 1989, p. 13). This study also made limited use of institutional isomorphism perspectives in its policy analysis. As shown in the work of DiMaggio and Powell (1983), organizations take into account the survival of other organizations in their environments, leading them to adopt similar behaviour, thereby decreasing systemic diversity.

Huisman (1998) derived the concept of diversity from its biological and ecological origins and determined the level of diversity by examining not only the number of species in a community but also the evenness of the distribution of organisms across species. A species is a population of organisms with the ability to interbreed freely and bring forth fertile offspring. Huisman transferred these concepts to provide insights about the level of diversity in higher education systems, where the system is the community, institutional types are the species, and higher education institutions are the organisms. The level of diversity in this study was therefore measured in reference to the variety of types (species) in the university sector in Ontario (biosystem) and the dispersion of universities (organisms) across types, by adopting a biological analogy similar to that of Huisman et al. (2007) for the purpose of data analysis and classification.

Quantitative research measures were used to determine the extent of diversity in Ontario's university sector in 1994 and 2010 by first using hierarchical cluster analysis. More specifically, this study determined the extent of systemic diversity and climate diversity during 1994 and 2010 by adapting Birnbaum's (1983) diversity matrix methodology to categorize institutions into institutional types; then it determined their concentration and 
dispersion by type. Simpson's $\lambda$, an indicator often used in ecology to measure diversity, was also used as another measure of systemic and climate diversity for 1994 and 2010.

The period 1994 to 2010 was selected because at that time, the higher education environment experienced a large number of changes including enrolment growth. The year 1994 was selected as a starting point for this study, as not only does it provide a long enough period to allow the system to change, but it captures the end of the New Democratic Party government's policies for higher education before the election of a Conservative government in June of 1995. The year 2010 was selected as it represents the end of the Liberal government's Reaching Higher Plan (even though the Liberals have remained in power since 2003) and is the latest year for which complete data were available.

An institution was included in the definition of Ontario's university sector if, during the period 1994 to 2010, the institution either held membership in the Association of Universities and Colleges of Canada (currently Universities Canada) or held membership (full or associate) in the Council of Ontario Universities. This study excluded institutions that had affiliation or federation arrangements with a comprehensive institution as these institutions formed an integral part of the comprehensive institution.

Following Morphew (2009), who limited his study to degree-granting institutions, this study focused on Ontario's university sector instead of its entire higher education system. The non-degree or college sector was excluded because a number of studies have already clearly laid out the differences between the college and university sectors (Jones, 1996, 2006; Skolnik, 1986, 2005). The university sector also operates in an environment that is quite distinct from that of the college or non-degree sector.

This study first used hierarchical cluster analysis, a technique used "for portioning objects into optimally homogenous groups on the basis of empirical measures of similarity among those objects" (Johnson, 1967, p. 241), to group together universities (unit of analysis) with similar characteristics (response variables). The practical result of the analysis was two branching diagrams (dendrograms), one for 1994 and one for 2010, that were compared to determine the extent of diversity in the university sector for these two years and the changes between them.

Nine response variables were used in the cluster analysis for both years, including variables used to operationalize systemic and climate diversity; these variables differentiate institutions and reflect their varying characters. They include the numbers of full-time faculty, full-time and part-time graduate enrolment, and full-time and part-time undergraduate enrolment. Financial characteristics that differentiate institutions by their main functions of education and research were also used: tuition fee revenue, operating grants, funding for sponsored research, and non-credit funding. Tuition fee revenue is a differentiating characteristic as it is impacted by the institution's tuition policy, the number of students, student mix by program, level of study, and proportion of international students served. Operating grant funding is impacted by the number of students enrolled and the student mix of programs. Since not all institutions offer the same extent and type of non-credit courses or conduct the same amount of research, these variables also differentiate institutions.

The hierarchical cluster analysis used Ward's method as its clustering algorithm, as suggested by Huisman (2000), and the (squared) Euclidean distance as its distance index, as recommended and favoured by Huberty, Jordan, and Brandt (2005). Ward's method uses an analysis of variance approach to evaluate the distances between clusters; 
it groups all cases into groups and proceeds until there is only one group. This method was more suitable for this study than the $k$-mean clustering algorithm, as it made no hypotheses concerning the number of clusters in 1994 and 2010. The subjectivity related to the choice of Ward's clustering algorithm over other algorithms was minimized since the same method was used for both 1994 and 2010. The Euclidean distance in univariate analysis is the arithmetical difference between two values. The squared Euclidean distance was used in order to place progressively greater weight on variables that are farther apart. As recommended by Milligan and Cooper (as cited in Huberty et al., 2005), since there is no common metric to the measurement of all variables, each variable was standardized using $z$ scores before the analysis was conducted using SPSS. It is acknowledged that an approach that uses a selection of meaningful dimensions by definition implies a loss of information.

The study more specifically assessed the change in systemic and climate diversity by adapting Birnbaum's (1983) methodology, which categorizes institutions into institutional types to determine their concentration and dispersion by type. Birnbaum's methodology was applied in two stages. The first stage consisted of determining the appropriate aspects of diversity to be measured that are consistent with education policy discourse in Ontario; the second stage involved applying various quantitative measures.

Systemic diversity was operationalized using two variables: size (small, medium, large) and type (primarily undergraduate, comprehensive, medical/doctoral, special-purpose). Climate diversity was operationalized using the following three variables: enrolment profile (low graduate, medium graduate, high graduate), undergraduate profile (low full-time, medium full-time, high full-time), and student-faculty contact (high contact, medium contact, low contact). The variables selected were limited to those that can be objectively quantified; they provided face validity, as they were generally accepted as variables reflecting differences among institutional forms and function in an Ontario context.

It should be noted that the method employed and the variables selected in this study differ from those used by Birnbaum (1983). First, Birnbaum used a matrix that yielded a total of 768 possible institutional types by categorizing each institution by control (four values); size (three values); sex of students (two values); curriculum (four values); highest degree level (four variables); and minority enrolment (two values). For the purposes of this study, the variables were adapted to accommodate the number of universities in Ontario, with a focus on systemic and climate diversity. While the control variable may be a differentiating factor in the United States, this is not the case in Ontario since most institutions (except Dominican University College and Redeemer University College) have the same form of control as publicly funded universities. A small number of private religious colleges operate in Ontario in a niche market, but they receive little attention in public discussions of higher education (Jones \& Young, 2004). For these reasons, this study did not use the control variable to assess systemic diversity. The sex of students variable is not relevant in Ontario since all universities are essentially coeducational public institutions. The highest degree level offered is not a discriminating variable in Ontario since only one small institution in the study does not offer graduate degrees. Categorizing institutions as minority institutions if more than 50\% of their enrolment is non-white would not have differentiated institutions in Ontario as the student population is extremely ethnically diverse, and institutions in Ontario do not define themselves as minority-serving institutions. 
The distribution by institutional types was completed by assigning each institution to one cell of the diversity matrix using only the two variables assessing systemic diversity and only the three variables assessing climate diversity. The possible number of institutional types to categorize each institution was determined to be the product of the values of each variable. For systemic diversity, the possible number of institutional types is 12 ( $3 \times 4$ ), and for climate diversity, the possible number of institutional types is 27 ( $3 \times 3$ $x$ 3). Each institution in the study was categorized using each of the five variables and identified to belong to one and only one of the possible institutional types. Therefore, institutions having the same identical values for all variables were viewed as belonging to the same institutional type, or sharing the same cell in the matrix. It should be noted that institutions belonging to the same institutional type are not identical in all aspects but share characteristics of their basic form and structure.

Quantitative measures of systemic and climate diversity were calculated using four indices, as suggested by Birnbaum (1983), to identify any significant change between 1994 and 2010.

- Index A measured the dispersion of institutions over the number of types. Index A was calculated by dividing the number of institutions in the province by the number of types they represent. The higher the index, the less the diversity.

- Index B measured the extent to which institutions were clustered together by examining the most densely populated cell of the diversity matrix. Index B was calculated by dividing the number of institutions in the most densely populated cell by the total number of institutions in the province (multiplied by 100 for ease of calculation). The higher the index, the less the diversity.

- Index $\mathrm{C}$ measured the extent to which institutions were concentrated within types. Index $\mathrm{C}$ was calculated by taking the proportion of institutions in the most highly populated $10 \%$ of the cells of the diversity matrix (multiplied by 100 for ease of calculation). The higher the index, the less the diversity.

- Index D measured the extent to which there were unique institutions in the sector. Index D was calculated by dividing the number of unique institutions (single institution in a cell in the matrix) by the total number of institutions (multiplied by 100 for ease of calculation). The higher the index, the more the diversity.

In the categorization of institutions by size and by type, the computed index values may have varied by year, depending on how each variable was defined. Since the categorization method was consistent for both 1994 and 2010, the yearly index values were not as significant by themselves but were calculated purely to determine the change over time. All differences were treated as equally important.

In ecology, the level of diversity is obtained from Simpson's $\lambda\left(\sum \mathrm{p}_{\mathrm{i}}{ }^{2}\right)$, which calculates "the probability that two institutions drawn at random from the population of higher education belong to the same institutional type" (Huisman et al., 2007, p. 569), where $\mathrm{p}_{\mathrm{i}}$ represents the proportional abundance of the ith institutional type. It was used in this study as a measure of systemic and climate diversity for 1994 and 2010. This measure used the number of institutional types as determined by adapting Birnbaum's (1983) methodology to the Ontario university sector and the total number of institutions. The closer the indicator was to 0 , the higher the diversity; the closer the indicator was to 1 , the lower the diversity. 


\section{Operationalizing the Variables: Systemic Diversity}

The classification of institutions by role and function facilitates the understanding of differences that exist among institutions (Altbach, 2002). This study assessed systemic diversity by classifying institutions by size and type, as is common in studies of diversity.

Institutional size is a variable that can be used to differentiate institutions. The American literature "consistently supports the existence of strong relationships between institutional size and other variables relating to activities, goals, campus climate and student outcomes" (Birnbaum, 1983, p. 88). This view was also shared by the Carnegie Foundation for the Advancement of Teaching, which stated that size does matter: "It is related to institutional structure, complexity, culture, finances, and other factors" (Carnegie Classification of Institutions of Higher Learning, n.d.-b, para. 2). Huisman et al. (2007) and the Carnegie Foundation for the Advancement of Teaching (Carnegie Classification of Institutions of Higher Learning, n.d.-b) defined large institutions as those with more than 10,000 students. Large institutions in a European context were defined as those institutions having 15,000 or more students; small institutions were those with fewer than 5,O0O students (U-Map, 2011). This study accepted that students would probably have similar experiences in institutions with more than 10,000 students; therefore it categorized institutions as small, if they had fewer than 5,000 students; medium, if they had between 5,000 and 10,000 students; or large, if they had more than 10,000 students.

In a Canadian context, universities have been differentiated by type for many years by Maclean's magazine when it ranks Canadian universities in November each year. The current categorization by Maclean's (primarily undergraduate, comprehensive, and medical/ doctoral) is well understood and generally accepted by universities and the public. Orton (2003) suggested using the Maclean's categorization and expanding it by two types, First Nations and Métis institutions and special-purpose organizations. This study accepted the categorization by Maclean's with the addition of Orton's (2003) two additional types, which were grouped together under the label special-purpose in an effort to minimize the number of values that could unduly inflate the number of institutional types.

\section{Operationalizing the Variables: Climate Diversity}

The variables used to assess climate diversity were enrolment profile, undergraduate profile, and student-faculty contact. The selection of values for each variable permitted differentiation between institutions while allowing similar institutions to be clustered together.

The enrolment profile variable categorized students according to the proportion enrolled in undergraduate and graduate programs and provided insight into the mission and climate of the institution. The Carnegie Foundation for the Advancement of Teaching stated that the mix of graduate and undergraduate students "reflects important differences with respect to educational mission as well as institutional climate and culture-differences that can have implications for infrastructure, services, and resource allocation" (Carnegie Classification of Institutions of Higher Learning, n.d.-a, para. 1). It classified institutions as exclusively undergraduate (two- and four-year institutions with no graduate programs), combined undergraduate and graduate/professional, or exclusively graduate/ professional (no undergraduate programs). Institutions that provided both undergraduate and graduate programs (all Ontario universities except Algoma University) were further 
characterized as having very high undergraduate enrolment (graduate students accounted for less than $10 \%$ of full-time equivalent, or FTE, enrolment), high undergraduate enrolment (graduate students accounted for between $10 \%$ and less than $25 \%$ of FTE enrolment), majority undergraduate enrolment (graduate students accounted for between 25\% and less than 50\% of FTE enrolment), and majority graduate/professional enrolment (graduate students accounted for at least 50\% of FTE enrolment). The European Classification of Higher Education Institutions, known as U-Map, chose not to use an indicator of graduate intensity in its teaching and learning profile dimension to avoid its hierarchical connotation. Instead, it used the following degree attributions, of which one or more may be attributed to a single institution: doctorate focus (more than $5 \%$ of all qualifications awarded were doctorate degrees), master focus (more than $25 \%$ of all qualifications awarded were master's degrees), bachelor focus (more than $40 \%$ of all qualifications awarded were bachelor's degrees), and sub-degree focus (more than $5 \%$ of all qualifications awarded were sub-degree qualifications) (U-Map, 2011). In Canada and in Ontario, few institutions have more than $25 \%$ of their student population in graduate studies. This study accepted that students would have a different experience in institutions where graduate students made up less than $10 \%$ of total enrolment than in institutions where graduate students made up more than $20 \%$ of total enrolment. Institutions were therefore categorized as low graduate, if they had less than 10\% full-time graduate students as a percentage of total full-time enrolment; medium graduate, if their graduate enrolment was between $10 \%$ and $20 \%$; or high graduate, if their graduate enrolment was above $20 \%$.

The undergraduate profile variable provided insight into the undergraduate climate and culture of the institution by distinguishing between the undergraduate students who attended on a full-time basis and those who attended on a part-time basis. The Carnegie Foundation for the Advancement of Teaching stated that part-time students were usually older and had a great zeal for learning but had competing obligations to juggle (Carnegie Classification of Institutions of Higher Learning, n.d.-c, para. 2). Institutions were categorized using the same values used by the Carnegie Foundation for the Advancement of Teaching for its examination of the undergraduate profile. An institution was categorized as low full-time, if full-time undergraduate students made up less than $60 \%$ of total undergraduate enrolment; medium full-time, if the percentage was between $60 \%$ and less than $80 \%$; or high full-time, if the percentage was $80 \%$ or higher.

The student-faculty contact variable was used because there is a widely held belief in the literature that one of the factors that lead to improved student engagement, satisfaction, and learning is increased student-faculty contact (e.g., Astin, 1985, 1993; Jacob, 1957; Lundberg \& Schreiner, 2004; Pascarella \& Terenzini, 1979; Wilson, Gaff, Dienst, Wood, \& Bavry, 1975). Kokkelenberg, Dillon, and Christy (2008), in their study of a public university, controlled for a number of variables such as student ability, level of student, gender, minority status, and academic department and determined that the grade point average declined as class size increased, precipitously up to a class size of 20 and more gradually through larger class sizes. Following these parameters, this study categorized institutions as high contact, if the ratio of total enrolment to full-time faculty was below 20; medium contact, if the ratio was between 20 and 30 ; or low contact, if the ratio was above 30. 


\section{Research Findings}

Figures 1 and 2 display the results of the hierarchical cluster analysis for 1994 and 2010.

Dominican College
Redeemer University College
Nipissing University
OCAD University
Lakehead University
Laurentian University
Wilfrid Laurier University
Trent University
Brock University
Windsor, University of
Ontario Institute for Studies in Educ
Ottawa, University of
York University
Western Ontario, University of
Carleton University
Waterloo, University of
Guelph, University of
McMaster University
Queen's University
Ryerson University
Toronto, University of

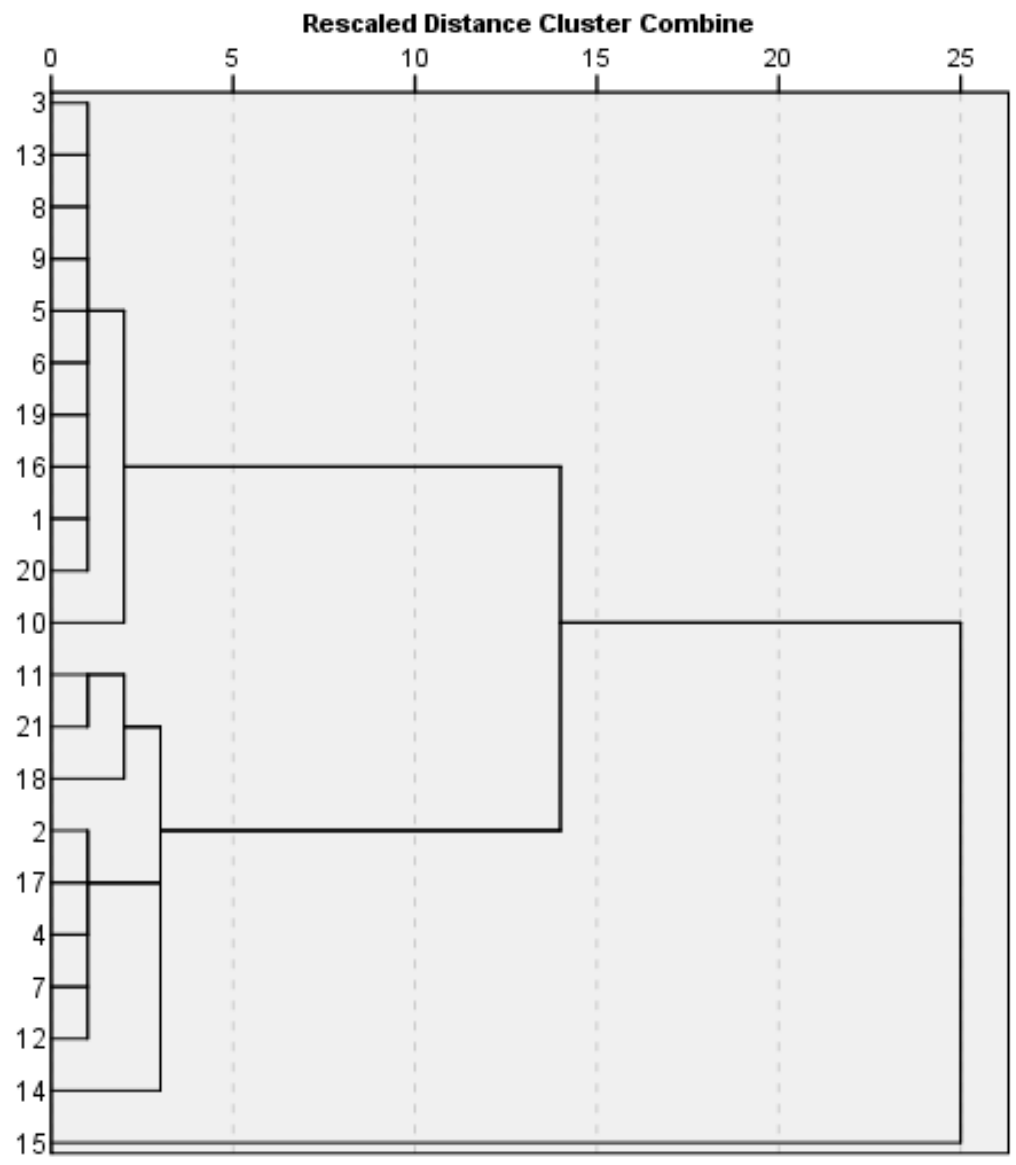

Figure 1. Dendrogram of Ontario Universities, 1994

A comparison of both dendrograms suggests that there has been very little change in diversity between 1994 and 2010, since universities in Ontario were clustered in three groups for both 1994 and 2010 and remained in the same cluster grouping in 2010 as they did in 1994. These results are further summarized in Figure 3: Universities were characterized as mainly undergraduate or research-intensive, with the University of Toronto sitting in a cluster of its own as it surpassed all universities on almost all of the variables considered. Weingarten et al. (2013) used a limited number of variables without the rigour of cluster analysis to arrive at similar clusters but determined that York, Carleton, Windsor, and Ryerson "do not fall easily into the two broad clusters of 'more research intensive' and "mainly undergraduate”" (p. 17). 


Algoma University
Redeemer University College
Dominican College
Laurentian University
Nipissing University
Lakehead University
Trent University
OCAD University
UOIT
Brock University
Wilfrid Laurier University
Windsor, University of
Guelph, University of
Queen's University
Carleton University
Waterloo, University of
McMaster University
Ottawa, University of
Western Ontario, University of
York University
Ryerson University
Toronto, University of

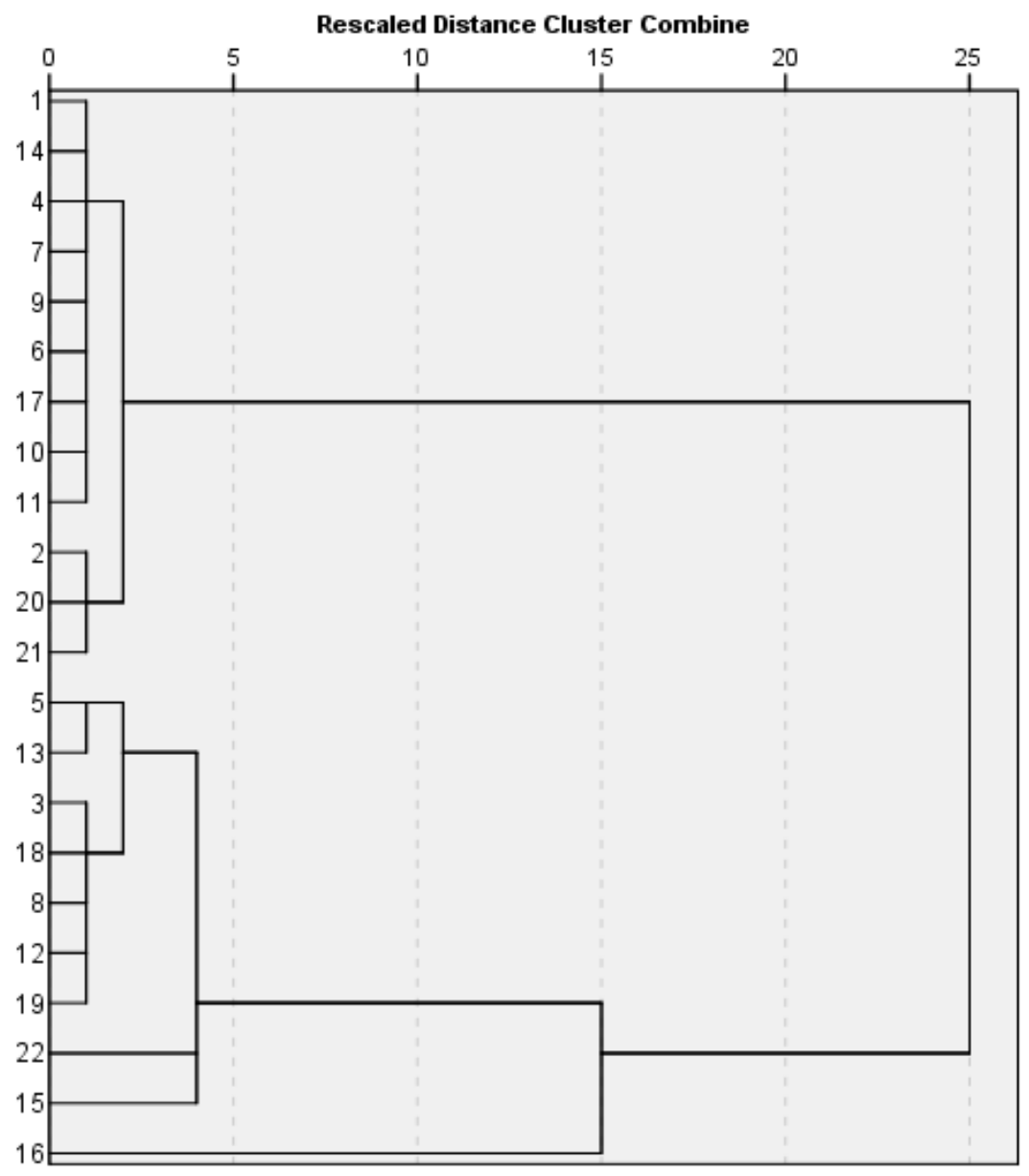

Figure 2. Dendrogram of Ontario Universities, 2010

Mainly Undergraduate

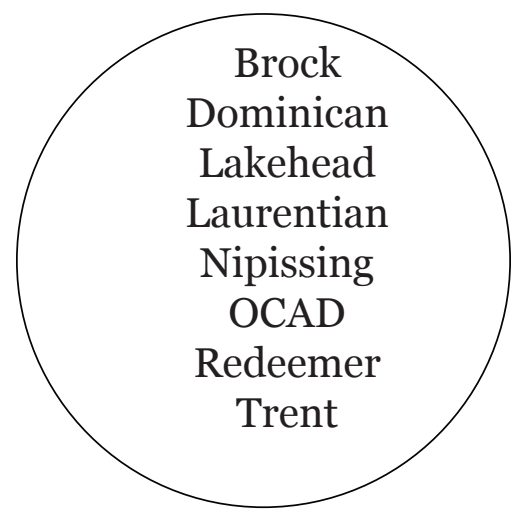

Research-Intensive

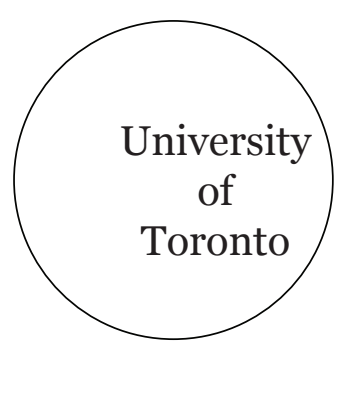

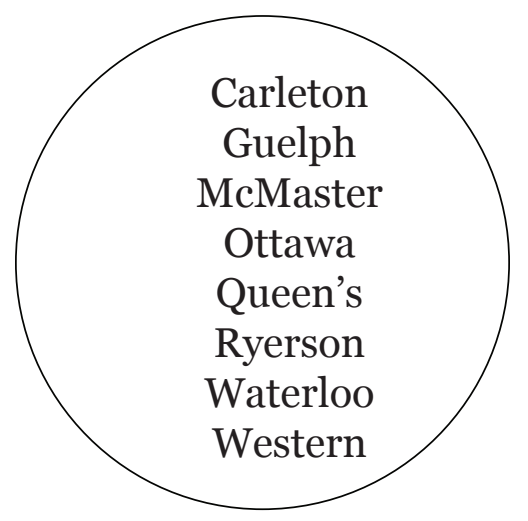

Figure 3. Clusters of Ontario Universities, 1994 and 2010 
The adaptation of Birnbaum's (1983) diversity matrix methodology to Ontario's university sector revealed a decrease in systemic diversity between 1994 and 2010. Table 2 displays the number of universities in each cell of the matrix for 1994 and 2010 (in parentheses). Ontario's university sector would be highly diverse if there were only one institution in each cell of the matrix or would be homogenous if all institutions belonged in one cell. Institutions belonged to six types in 1994, as compared with only five types in 2010; there was one institution alone in one cell in 1994 and none in 2010, which suggested a decrease in systemic diversity from 1994 to 2010. System enrolment growth clearly contributed to the decrease in diversity as one institution moved from the small category to medium and another moved from medium to large.

Table 2.

Systemic Diversity in Ontario Universities, 1994 and 2010

\begin{tabular}{lcccc}
\hline & $\begin{array}{c}\text { Primarily } \\
\text { undergraduate }\end{array}$ & $\begin{array}{c}\text { Comprehen- } \\
\text { sive }\end{array}$ & $\begin{array}{c}\text { Medical/ } \\
\text { doctoral }\end{array}$ & $\begin{array}{c}\text { Special- } \\
\text { purpose }\end{array}$ \\
\hline Large & $2(3)$ & $5(5)$ & $5(5)$ & \\
Medium & $4(5)$ & & & \\
Small & 1 & & & $5(5)$ \\
\hline \multicolumn{2}{l}{ Note: 2010 figures are in parentheses. }
\end{tabular}

The indices suggested by Birnbaum (1983) provided a numerical summary of the extent of diversity. Table 3 summarizes the indices for both 1994 and 2010 for systemic diversity.

Table 3 .

Four Simple Diversity Indices of Systemic Diversity, 1994 and 2010

\begin{tabular}{|c|c|c|c|c|c|}
\hline \multirow[t]{2}{*}{ Index } & \multicolumn{2}{|c|}{1994} & \multicolumn{2}{|c|}{2010} & \multirow{2}{*}{$\begin{array}{c}\text { Change in } \\
\text { diversity } \\
\text { since } 1994\end{array}$} \\
\hline & Calculation & Index value & Calculation & Index value & \\
\hline Birnbaum A & $22 / 6$ & 3.7 & $23 / 5$ & 4.6 & Decrease \\
\hline Birnbaum B & $5 / 22 \times 100$ & 22.7 & $5 / 23 \times 100$ & 21.7 & Unchanged \\
\hline Birnbaum C & $3 / 22 \times 100$ & 13.6 & $2.5 / 23 \times 100$ & 10.9 & Increase \\
\hline Birnbaum D & $1 / 22 \times 100$ & 4.5 & $0 / 23 \times 100$ & 0.0 & Decrease \\
\hline
\end{tabular}

The level of systemic diversity was further summarized numerically for 1994 and 2010 using Simpson's $\lambda$. The larger the number of types of higher education institutions and the more institutions were evenly distributed across a large number of types, the more diverse the system. The closer the indicator was to o, the higher the diversity. In 1994, there were 22 institutions distributed across six types. Simpson's $\lambda$ is consequently $(5 / 22)^{2}+(5 / 22)^{2}$ $+(5 / 22)^{2}+(4 / 22)^{2}+(2 / 22)^{2}+(1 / 22)^{2}=0.1983$. In 2010, there were 23 institutions 
distributed across five types. Simpson's $\lambda$ is consequently $(5 / 23)^{2}+(5 / 23)^{2}+(5 / 23)^{2}+$ $(5 / 23)^{2}+(3 / 23)^{2}=0.2060$. Using Birnbaum's indices and the calculation of Simpson's $\lambda$, there appeared to be a decrease in systemic diversity between 1994 and 2010.

The adaptation of Birnbaum's (1983) diversity matrix methodology to Ontario's university sector revealed a decrease in climate diversity between 1994 and 2010. Figure 5 displays the number of universities in each cell of the matrix for 1994 and 2010. Institutions belonged to 10 types in 1994 and 2010 (suggesting no change in diversity) but were more concentrated in 2010: One type had six institutions in 2010 compared with four institutions in 1994 (suggesting less diversity); in 2010, five institutions were alone in the matrix, compared with four in 1994 (suggesting more diversity).

1994

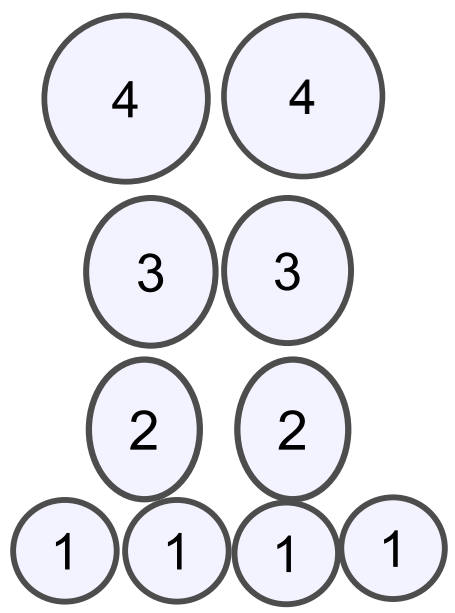

2010

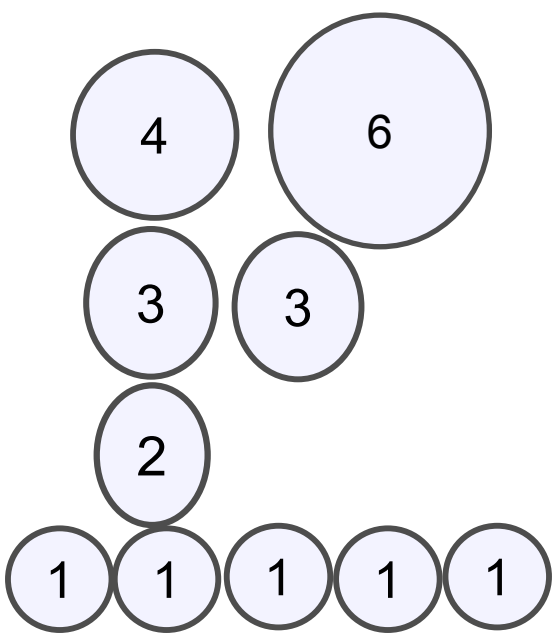

Figure 5. Climate Diversity in Ontario Universities, 1994 and 2010

Table 4 summarizes the indices for both 1994 and 2010 for systemic diversity.

Table 4 .

Four Simple Diversity Indices of Climate Diversity, 1994 and 2010

\begin{tabular}{lcclccc}
\hline Index & \multicolumn{2}{c}{1994} & & \multicolumn{2}{c}{2010} & Change in \\
\cline { 2 - 3 } & Calculation & Index value & & Calculation & Index value & $\begin{array}{c}\text { diversity } \\
\text { since 1994 }\end{array}$ \\
\hline Birnbaum A & $22 / 10$ & 2.2 & & $23 / 10$ & 2.3 & Unchanged \\
Birnbaum B & $4 / 22 \times 100$ & 18.2 & & $6 / 23 \times 100$ & 26.1 & Decrease \\
Birnbaum C & $4 / 22 \times 100$ & 18.2 & & $6 / 23 \times 100$ & 26.1 & Decrease \\
Birnbaum D & $4 / 22 \times 100$ & 18.2 & & $5 / 23 \times 100$ & 21.7 & Increase \\
\hline
\end{tabular}


The level of climate diversity was further summarized numerically for 1994 and 2010 using Simpson's $\lambda$. In 1994, there were 22 institutions distributed across 10 types. Simpson's $\lambda$ is consequently $(4 / 22)^{2}+(4 / 22)^{2}+(3 / 22)^{2}+(3 / 22)^{2}+(2 / 22)^{2}+(2 / 22)^{2}+$ $(1 / 22)^{2}+(1 / 22)^{2}+(1 / 22)^{2}+(1 / 22)^{2}=0.1281$. In 2010, there were 23 institutions distributed across 10 types. Simpson's $\lambda$ is consequently $(6 / 23)^{2}+(4 / 23)^{2}+(3 / 23)^{2}+(3 / 23)^{2}$ $+(2 / 23)^{2}+(1 / 23)^{2}+(1 / 23)^{2}+(1 / 23)^{2}+(1 / 23)^{2}+(1 / 23)^{2}=0.1493$. Using Birnbaum's indices and the calculation of Simpson's $\lambda$, there appeared to be a decrease in climate diversity between 1994 and 2010.

\section{Discussion and Policy Implications}

It is understood that Ontario is experiencing a slow economic recovery, with increased demand for baccalaureate education. The Ontario government has already signalled that it is ready "to steer the system in ways that align with provincial priorities while respecting the autonomy and supporting the strengths of our institutions" (Ontario Ministry of Training, Colleges and Universities, 2013, p. 6) through the use of a number of metrics. It has also identified that its key goals in differentiating the post-secondary sector in Ontario are to "support student success and access to a high-quality Ontario postsecondary education, improve the global competitiveness of Ontario's postsecondary education system, build on and help focus the well-established strengths of Ontario colleges and universities while avoiding unnecessary duplication, [and] maintain an efficient and financially sustainable postsecondary education system" (Ontario Ministry of Training, Colleges and Universities, 2013, p. 9). Detailed implementation plans have not been developed as of January 2014.

While an in-depth analysis of the factors that contributed to the convergence of universities in Ontario is beyond the scope of this study (for an analysis of factors that promoted or hindered processes of diversity in Ontario's university sector, see Piché, 2015), broad policy implications will be considered here by drawing on the work of Codling and Meek (2006) and their observations of Australia's and New Zealand's higher education systems.

Codling and Meek (2006) contended that strong government policies are required to sustain differences between institutions. Without these policies, institutional convergence would occur when institutions were subjected to uniform environmental conditions. The Ontario government's differentiation framework provides a foundation to further diversify the post-secondary sector by strategically managing institutional enrolment growth with provincial policies. The government will need to take a more central planning role that will recognize program strengths while accepting that universities cannot be everything to everyone. The Strategic Mandate Agreement process that unfolded in early 2014 recognizes the need for increased planning.

Codling and Meek (2006) also contended that financial incentives should have clear diversity objectives; the creation of a competitive environment promotes convergence tendencies, as institutions tend to copy one another in periods of increased financial resources. Diversification in Ontario's university sector can be achieved only by providing the required incentives to autonomous institutions with clear diversity objectives (efficiency, effectiveness, accessibility, instructional quality, and/or research quality). This will require the government to prioritize its diversity objectives before allocating any funding. 
While funding policies could be individually determined for each university, "many differentiation frameworks cluster like-minded institutions into categories in that institutions share the same rights and responsibilities as others in their cluster" (Weingarten et al., 2013, p. 7). As previously illustrated through hierarchical cluster analysis (see Figure 3), institutions in Ontario can be grouped in three clusters. The University of Toronto is in a cluster of its own. The primarily undergraduate cluster includes Algoma, Redeemer, Dominican, Laurentian, Nipissing, Lakehead, Trent, OCAD, UOIT, Brock, Wilfrid Laurier, and Windsor; and the research-intensive cluster includes Guelph, Queen's, Carleton, Waterloo, McMaster, Ottawa, Western, York, and Ryerson. It is understood that grouping institutions into three clusters may be contested by institutions, as these clusters were derived purely from a limited number of quantitative indicators without the benefit of any relevant qualitative factors (regional preferences or the need to address social or economic benefits). A different funding formula could be determined for each cluster that would allocate funding on a competitive basis within each cluster (forcing the convergence of institutions within a cluster), with institutions providing detailed proposals (with performance indicators) while specifically addressing government diversity objectives set for each cluster. Proposals could be reviewed by an international panel of experts that would advise the government on funding allocations by institution. Different funding formulas by cluster would also allow, for example, the primarily undergraduate cluster to be funded in such a way as to reduce class size, while the University of Toronto cluster could receive funding for its international graduate students.

\section{Limitations and Future Research}

This study quantitatively examined systemic and climate diversity in Ontario's university sector. While the research design selected for this study does not permit the extrapolation of the results to other university sectors in Canada or elsewhere, the measurement methodology employed in this study could be applied in other university sectors in Canada in order to assess diversity from a pan-Canadian perspective. This approach and methodology could also be applied to other countries; in doing so, it would be necessary for researchers elsewhere to determine the variables that would be most relevant to the higher education policy context in their jurisdictions.

Future research in this area could consider whether this model can be applied to Ontario's higher education system as a whole instead of being limited to its university sector. The model could also be extended to consider the impact of satellite campuses on systemic and climate diversity by disaggregating institutional data by campus. A detailed examination of Ontario's programmatic diversity through empirical analysis (see, for example, Lepori et al., 2014; Rossi, 2010; Teixeira et al., 2011) could also add to the limited literature of diversity and continue to fuel the debate about institutional diversity.

This study operationalized institutional climate from a student profile and experience perspective. Further studies may wish to consider a broader definition of institutional climate by considering other variables such as research intensity (number of publications or citations, share of federal granting council funding) or through an examination of institutional missions that go beyond teaching and research. 


\section{Acknowledgements}

I would like to thank Professor Glen Jones, Professor Michael Skolnik, and Dr. Stacey Young for the guidance and thoughtful advice they gave throughout my doctoral studies that contributed to the overall quality of this study.

\section{References}

Altbach, P. G. (2002). Differentiation requires definition: The need for classification in complex academic systems. International Higher Education, 26, 2-3.

Astin, A. W. (1985). Achieving educational excellence. San Francisco, CA: Jossey-Bass.

Astin, A. W. (1993). What matters in college: Four critical years revisited. San Francisco, CA: Jossey-Bass.

Birnbaum, R. (1983). Maintaining diversity in higher education. San Francisco, CA: Jossey-Bass.

Carnegie Classification of Institutions of Higher Learning. (n.d.-a). Classification description:Enrollmentprofileclassification.Retrievedfromhttp://carnegieclassifications. iu.edu/descriptions/enrollment_profile.php

Carnegie Classification of Institutions of Higher Learning. (n.d.-b). Classification description: Size \& setting. Retrieved from http://carnegieclassifications.iu.edu/ descriptions/size_setting.php

Carnegie Classification of Institutions of Higher Learning. (n.d.-c). Classification description: Undergraduate profile classification. Retrieved from http:// carnegieclassifications.iu.edu/descriptions/undergraduate_profile.php

Codling, A., \& Meek, V. L. (2006). Twelve propositions on diversity in higher education. Higher Education Management and Policy, 18(3), 1-24.

DiMaggio, P. J., \& Powell, W. W. (1983). The iron cage revisited: Institutional isomorphism and collective rationality in organizational fields. American Sociological Review, 48, 147-160.

Fallis, G. (2013). Rethinking higher education: Participation, research and differentiation. Montreal, QC, and Kingston, ON: Queen's Policy Studies Series, McGillQueen's University Press.

Hannan, M. T., \& Freeman, J. (1989). Organizational ecology. Cambridge, MA: Harvard University Press.

Hicks, M., Weingarten, H. P., Jonker, L., \& Liu, S. (2013). The diversity of Ontario's colleges: A data set to inform the differentiation discussion. Toronto, ON: Higher Education Quality Council of Ontario.

Huberty, C. J., Jordan, E. M., \& Brandt, W. C. (2005). Cluster analysis in higher education research. In J. C. Smart (Ed.), Higher education: Handbook of theory and research, Vol. $2 O$ (pp. 437-457). Dordecht, Netherlands: Springer.

Huisman, J. (1998). Differentiation and diversity in higher education systems. In J. C. Smart (Ed.), Higher education: Handbook of theory and research, Vol. 13 (pp. 75-110). New York, NY: Agathon Press. 
Huisman, J. (2000). Higher education institutions: As different as chalk and cheese? Higher Education Policy, 13(1), 41-53.

Huisman, J., Meek, L., \& Wood, F. (2007). Institutional diversity in higher education: A cross-sectional and longitudinal analysis. Higher Education Quarterly, 61(4), 563-77.

Jacob, P. (1957). Changing values in college: An exploratory study of the impact of college teaching. New York, NY: Harper.

Johnson, S. C. (1967). Hierarchical clustering schemes. Psychometrika, 32(3), 241254 .

Jones, G. A. (1996). Diversity within a decentralized higher education system: The case for Canada. In V. L. Meek, L. Goedegebuure, O. Kivinen, \& R. Rinne (Eds.), The mockers and mocked: Comparative perspectives on differentiation, convergence and diversity in higher education (pp. 79-94). Oxford, UK: Pergamon.

Jones, G. A. (2006). Canada. In J. J. F. Forest \& P. G. Altbach (Eds.), International handbook of higher education, Pt. 1 (pp. 627-645). Dordecht, Netherlands: Springer.

Jones, G. A., \& Young, S. J. (2004). "Madly off in all directions": Higher education, marketization and Canadian federalism. In P. Teixeira, B. Jongbloed, D. D. Dill, \& A. Amaral (Eds.), Markets and higher education (pp. 185-205). London, UK: Kluwer Academic Publishers.

Kokkelenberg, E. C., Dillon, M., \& Christy, S. M. (2008). The effects of class size on student grades at a public university. Economics of Education Review, 27(2), 221-233.

Lepori, B., Huisman, J., \& Seeber, M. (2014). Convergence and differentiation processes in Swiss higher education: An empirical analysis. Studies in Higher Education, 39(2), 197-218.

Lundberg, C. A., and Schreiner, L. A. (2004). Quality and frequency of faculty-student interactions as a predictor of learning: An analysis by student race/ethnicity. Journal of College Student Development, 45(5), 549-566.

Morphew, C. C. (2009). Conceptualizing change in the institutional diversity of U.S. colleges and universities. The Journal of Higher Education, 8o(3), 243-269.

Ontario Ministry of Training, Colleges and Universities. (2013). Ontario's differentiation policy framework for postsecondary education. Toronto, ON: Queen's Printer for Ontario.

Orton, L. (2003). A new understanding of postsecondary education in Canada: A discussion paper. Ottawa, ON: Statistics Canada. Catalogue No. 81-595-MIE2003011.

Pascarella, E. T., \& Terenzini, P. T. (1979). Student-faculty informal contact and college persistence: A further investigation. Journal of Educational Research, 72, 214-218.

Piché, P. G. (2015). Institutional diversity and funding universities in Ontario: Is there a link? Journal of Higher Education Policy and Management, 37(1), 52-68.

Rossi, F. (2010). Massification, competition and organizational diversity in higher education: Evidence from Italy. Studies in Higher Education, 35(3), 277-300.

Skolnik, M. L. (1986). Diversity in higher education: The Canadian case. Higher Education in Europe, 11(2), 19-32. 
Skolnik, M. L. (2005). A discussion of some issues pertaining to the structure of postsecondary education in Ontario and some suggestions for addressing them. College Quarterly, 8(1). Retrieved from http://collegequarterly.ca/index.html

Stanley, G., \& Reynolds, P. (1994). Similarity grouping of Australian universities. Higher Education, 27(3), 359-366.

Teixeira, P. N., Rocha, V., Biscaia, R., \& Cardoso, M. F. (2012). Competition and diversity in higher education: An empirical approach to specialization patterns of Portuguese institutions. Higher Education, 63(3), 337-352.

U-Map. (2011).Overview of indicators and data-elements, by dimension. Retrieved from http://www.u-map.eu/U-Map\%20dimensions\%20and\%20indicators\%2odetail.pdf

Weingarten, H. P., Hicks, M., Jonker, L., \& Liu, S. (2013). The diversity of Ontario's universities: A data set to inform the differentiation discussion. Toronto, ON: Higher Education Quality Council of Ontario.

Wilson, R., Gaff, J., Dienst, E., Wood, L., \& Bavry, J. (1975). College professors and their impact on students. New York, NY: Wiley \& Sons.

Zha, Q. (2009). Diversification or homogenization: How governments and markets have combined to (re)shape Chinese higher education in its recent massification process. Higher Education, 58(1), 41-58.

\section{Contact Information}

Pierre Gilles Piché

Financial Services Department

University of Toronto

pierre.piche@utoronto.ca

Pierre Gilles Piché is a chartered professional accountant and controller and director of financial services at the University of Toronto. He holds a doctor of philosophy degree in higher education from the University of Toronto. He is an active member of the Council of Ontario Finance Officers and the Canadian Association of University Business Officers. His research interests include issues of institutional diversity, finance, and accountability. 